\title{
Regulation of estrogen receptor- $\alpha$ expression in MCF-7 cells by taxol
}

\author{
M B Martin, S V Angeloni ${ }^{1}$, P Garcia-Morales ${ }^{2}$, P F Sholler, \\ M D Castro-Galache ${ }^{3}$, J A Ferragut ${ }^{3}$ and M Saceda $^{2,3}$
}

Departments of Oncology and Biochemistry and Molecular Biology, Vincent T Lombardi Cancer Center, Georgetown University, Washington DC 20057, USA

${ }^{1}$ Center for Vaccine Development, University of Maryland School of Medicine, Baltimore, Maryland 21201, USA

${ }^{2}$ Hospital General Universitario de Elche, 03202 Elche, Alicante, Spain

${ }^{3}$ Instituto de Biología Molecular y Celular, Universidad Miguel Hernandez, 03202 Elche, Alicante, Spain

(Requests for offprints should be addressed to M Saceda, Centro de Biología Molecular y Celular, Ed. Torregaitan, Universidad Miguel Hernández, 03202 Elche, Alicante, Spain; Email: msaceda@umh.es)

\begin{abstract}
Results presented in this study demonstrate that treatment of MCF-7 cells with taxol resulted in induction of estrogen receptor- $\alpha(\operatorname{ER} \alpha)$ gene transcription with a subsequent increase in ER $\alpha \mathrm{mRNA}$; this effect was promoter specific since taxol did not affect total transcription in MCF-7 cells and lacked an effect on transcription of the human acidic ribosomal phosphoprotein protein $\mathrm{PO}$, progesterone receptor, and pS2 genes. In contrast to the increase in transcription of the ER $\alpha$ gene, taxol inhibited translation
\end{abstract}

of the ER $\alpha$ mRNA. This effect is also transcript specific since taxol did not alter total protein synthesis and did not affect the concentration of progesterone receptor protein in the cell. The overall result of taxol treatment was to decrease the concentration of $\mathrm{ER} \alpha$ protein in the MCF-7 cells. Evidence is presented that the effects of taxol on $\operatorname{ER} \alpha$ gene transcription may be mediated through the induction of p53.

Journal of Endocrinology (2004) 180, 487-496

\section{Introduction}

The presence of estrogen receptor- $\alpha(\mathrm{ER} \alpha)$ and progesterone receptor $(\mathrm{PR})$ in breast tumors is used to predict those patients who would benefit from hormonal therapy (Allegra \& Lippman 1980, DeSombre \& Jensen 1980, Osborne et al. 1980, Paridaens et al. 1980). Unfortunately a high percentage of receptor-positive tumors become resistant to this therapy. The mechanism responsible for the loss of estrogen responsiveness in human breast cancer remains unclear and it is the reason for the broad interest in studying the regulation of $\operatorname{ER} \alpha$ gene expression. The results from these studies suggested that regulation of the steady-state level of ER $\alpha$ in breast cancer cells is a complex phenomenon that includes transcriptional and post-transcriptional mechanisms (Saceda et al. 1988, 1991, 1996, Lee et al. 1989, Cho et al. 1991, Garcia-Morales et al. 1994, Martin et al. 1995, Stoica et al. 1997, 2000a,b) which are tightly regulated by a variety of agents including estradiol (Saceda et al. 1988, Cho et al. 1991), phorbol esters (Lee et al. 1989, Saceda et al. 1991, Martin et al. 1995), growth factors (Saceda et al. 1996, Stoica et al. 1997, 2000a,b), and heavy metals (Garcia-Morales et al. 1994). In this study, the effects of taxol on ER $\alpha$ expression in MCF-7 cells were investigated. Taxol, a diterpenoid isolated from the Pacific yew Taxus brevifolia (Wani et al.
1971, Adams et al. 1993), has been used extensively as an anticancer drug (Long 1994, Crown \& O’Leary 2000, Mukherjee et al. 2001). It is effective in several types of cancer, particularly in some hormone-related cancers such as breast carcinoma (Fornier et al. 2000). Taxol has multiple biological effects, including inhibition of cell division (Milas et al. 1995, Milross et al. 1996), inhibition of fibroblast migration (Joseph et al. 1989), changes in cell morphology (Pletjushkina et al. 1994), and alteration of the expression of genes, such as the tumor suppressor gene p53 (Tishler et al. 1995) and tumor necrosis factor (TNF) (Burkhart et al. 1994). Some of the effects of taxol appear to be related to its influence on the tubulin-microtubule system (Schiff \& Horwitz 1980). Taxol promotes assembly of microtubules and stabilizes them against depolymerizing agents. Taxol has also been reported to have effects that are mediated by mechanisms other than its interaction with microtubules (Moos \& Fitzpatrick 1998, Srivastava et al. 1998, Stein 1999, Wang et al. 1999). In chromaffin cells, taxol affects catecholamine secretion. Following exposure to taxol, there is an initial increase in catecholamine secretion that is mediated by an increase in intracellular $\mathrm{Ca}^{2+}$ followed by an inhibition in catecholamine secretion that is mediated by its effect on microtubules (ThuretCarnahan et al. 1985, Gomez et al. 2000). In the present study, the effects of taxol on $\operatorname{ER} \alpha$ expression in MCF-7 
human breast carcinoma cells were investigated and we have also demonstrated a dual effect of the drug on ER $\alpha$ expression. Treatment of cells with taxol resulted in an induction of ER $\alpha$ gene transcription that was accompanied by an increase in ER $\alpha$ mRNA. In contrast to its effect on transcription, taxol inhibited translation of the ER $\alpha$ mRNA. The overall result of taxol treatment was a decrease in the steady-state level of ER $\alpha$ protein. The effects of taxol appear to be specific for ER $\alpha$ expression since transcription and protein synthesis were not affected by treatment with the drug. Evidence is also presented suggesting that the increase in ER $\alpha$ transcription may be mediated through the induction of $\mathrm{p} 53$.

\section{Materials and Methods}

\section{Tissue culture}

Monolayer cultures of MCF-7 human breast cancer cells were grown in improved minimal essential medium (IMEM) supplemented with 5\% (v/v) fetal calf serum (FCS). When the cells were $80 \%$ confluent, the medium was replaced with phenol red-free IMEM containing 5\% charcoal-treated calf serum (CCS) (Berthois et al. 1986). The CCS was pretreated with sulfatase and dextran-coated charcoal to remove endogenous steroids. After 2 days in these conditions, taxol (ICN pharmaceuticals, Costa Mesa, CA, USA), cycloheximide (Sigma), or both were added and the cells were harvested at the times indicated.

\section{ERa assays}

Enzyme immunoassay For determination of the concentration of ER $\alpha$ protein, MCF-7 cells were cultured and treated as described above. The amount of ER $\alpha$ protein was assayed using an enzyme immunoassay kit containing monoclonal antibodies to ER $\alpha$ from Abbott Laboratories (North Chicago, IL, USA). To obtain total ER $\alpha$, the cells were homogenized by sonication in a high salt buffer (10 mM Tris, $1.5 \mathrm{mM}$ EDTA, $5 \mathrm{mM} \mathrm{Na} \mathrm{MoO}_{4}, 0.4 \mathrm{M}$ $\mathrm{KCl}, 1 \mathrm{mM}$ monothioglycerol, and $2 \mathrm{mM}$ leupeptin). The homogenate was incubated on ice for $30 \mathrm{~min}$ and centrifuged at $10000 \mathrm{~g}$ for $1 \mathrm{~h}$ at $4{ }^{\circ} \mathrm{C}$. Aliquots of the total extracts were then analyzed according to the manufacturer's instructions.

\section{Western blot}

Treated or untreated MCF-7 cells were washed twice with phosphate-buffered saline (PBS). Cells were scraped and centrifuged at $1000 \boldsymbol{g}$ for $5 \mathrm{~min}$. The cellular pellet was resuspended in RIPA buffer $(150 \mathrm{mM} \mathrm{NaCl}, 1 \%$ NP-40, $0 \cdot 5 \%$ deoxycholate, $0 \cdot 1 \%$ SDS, and $50 \mathrm{mM}$ Tris $(\mathrm{pH})$ ) and protease and phosphatase inhibitors were added. Cells were kept on ice for $30 \mathrm{~min}$ and centrifuged at $16000 \boldsymbol{g}$ for $15 \mathrm{~min}$ at $4{ }^{\circ} \mathrm{C}$. The cellular pellet was discarded, and the protein content of the cell extract (supernatant) was determined using the Bradford method (Bio-Rad, Richmond, CA, USA). ER expression was determined by Western blot using the monoclonal antibody anti-ER $\alpha$ (D-12) (Santa Cruz Biotechnology Inc., Santa Cruz, CA, USA) followed by enhanced chemiluminescence (Amersham International, Amersham, Bucks, UK) to develop protein bands.

\section{Western blot in cells membrane extracts}

Treated or untreated MCF-7 cells were washed with PBS and centrifuged at $800 \boldsymbol{g}$ for $8 \mathrm{~min}$. The cellular pellet was resuspended in $1 \mathrm{ml}$ membrane buffer ( $5 \mathrm{mM}$ EDTA, $200 \mathrm{mM} \mathrm{NaCl}$, and $10 \mathrm{mM}$ Tris (pH7.4)) in the presence of protease inhibitors, and homogenized (100 strokes with a dounce homogenizer and three pulses with a politron). The homogenate was centrifuged at $16000 \boldsymbol{g}$ for $20 \mathrm{~min}$ at $4{ }^{\circ} \mathrm{C}$. Ultracentrifugation of the supernatant at $100000 \mathrm{~g}$ for $1 \mathrm{~h}$ at $4{ }^{\circ} \mathrm{C}$ was performed and the pellet was resuspended in membrane buffer. ER expression was determined by Western blot as described above.

\section{Plasmids}

The clones for ER $\alpha$, pOR300 (Saceda et al. 1988) and Q7 (Garcia-Morales et al. 1994), for the PR (Saceda et al. 1988) and pPR250 (Garcia-Morales et al. 1994), for pS2 (Saceda et al. 1988), and for the human acidic ribosomal phosphoprotein protein PO (Saceda et al. 1988) and p36B4 (Saceda et al. 1988) have been described previously. The riboprobe for $\mathrm{p} 53$ is an NcoI fragment subcloned into pGEM 7z (kindly provided by Dr Daniel Eliahu). The wild-type p53 expression vector pC53-SN3 was a kind gift from Dr Bert Vogelstein (Baker et al. 1990, Kern et al. 1992). This vector expresses wild-type p53 under the control of the cytomegalovirus (CMV) promoter. The p53-EGFP chimera expression vector pp53-EGFP from Clontech Laboratories Inc. (CA, USA) contains a p53EGFP expression cassette driven by the immediate-early CMV promoter. The SV40 poly A sequence is included for proper processing of the $3^{\prime}$ end of the fusion construct. The vector also contains a neomycin resistance cassette driven by the SV40 early promoter.

\section{Measurement of cellular ERa $m R N A$}

Total cellular RNA was extracted from MCF-7 cells by the method of Chomczynski \& Sacchi (1987). The amount of ER $\alpha$ mRNA was determined by RNase protection analysis. In summary, homogeneously ${ }^{32} \mathrm{P}-$ labeled antisense molecules (cRNA) were synthesized in vitro from $\mathrm{pOR} 300$ (ER $\alpha$ riboprobe) and $\mathrm{p} 36 \mathrm{~B} 4$ using T7 polymerase. Total RNA $(60 \mu \mathrm{g})$ was hybridized for 12-16 $\mathrm{h}$ to the radiolabeled cRNA. After a 30-min digestion at $25{ }^{\circ} \mathrm{C}$ with RNase A, ${ }^{32} \mathrm{P}$-labeled cRNA probes protected from RNase digestion were resolved by electrophoresis on $6 \%$ polyacrylamide gels. The bands 
were visualized by autoradiography and quantified by optical densitometry. The amount of ER mRNA was normalized to the amount of the internal control 36B4, which is the cDNA of the human acidic ribosomal phosphoprotein PO.

\section{Isolation of nuclei}

Nuclei from MCF-7 cells were isolated after treatment by a method described previously (Saceda et al. 1988). Briefly, the cells were harvested in $5 \mathrm{ml}$ PBS and pelleted by gentle centrifugation at $4{ }^{\circ} \mathrm{C}$. The pellet was resuspended in lysis buffer $(10 \mathrm{mM}$ Tris, $\mathrm{pH} 7 \cdot 5,10 \mathrm{mM} \mathrm{NaCl}, 3 \mathrm{mM}$ $\mathrm{MgCl}_{2}$, and $\left.0.5 \% \mathrm{NP}-40\right)$. After $5 \mathrm{~min}$ on ice, the cells were centrifuged at $500 \mathrm{~g}$ at $4{ }^{\circ} \mathrm{C}$ for $5 \mathrm{~min}$. The pellet was again resuspended in $4 \mathrm{ml}$ lysis buffer and centrifuged as described above. The pellet from the second centrifugation was resuspended in $500 \mu \mathrm{l}$ nuclei storage buffer $(20 \mathrm{mM}$ HEPES, $75 \mathrm{mM} \mathrm{NaCl}, 0.5 \mathrm{mM}$ EDTA, $0.85 \mathrm{mM}$ dithiothreitol (DTT), $0.125 \mathrm{mM}$ phenylmethylsulfonylfluoride, and $50 \%$ glycerol). Nuclei were stored at $-70{ }^{\circ} \mathrm{C}$ until the transcription elongation assay was performed.

\section{Transcription elongation assay}

The nuclear transcription run-on assay was performed as previously described (Saceda et al. 1988). Nuclei were isolated at various times after administration of taxol as described above. Isolated nuclei were incubated with ${ }^{32} \mathrm{P}-\mathrm{UTP}$ and unlabeled ATP, CTP, and GTP. Radiolabeled RNA transcripts were isolated and hybridized to an excess of denatured plasmid DNA immobilized on a nitrocellulose membrane. Denatured plasmids used for detection of specific transcripts were exon 1 of $E R \alpha(Q 7)$, ribosomal protein $\mathrm{PO}$, glyceraldehyde-3-phosphate dehydrogenase (GAPDH), pS2, and PR. Autoradiographs were analyzed by densitometry and the background was subtracted. The results were normalized to the transcriptional level of the ribosomal protein PO gene.

\section{Total transcription}

Nuclei from MCF-7 cells were isolated after incubation with taxol at different intervals as described above. The nuclear transcription assay was performed as described above except that $5 \mu \mathrm{Ci}^{3} \mathrm{H}-\mathrm{UTP}$ were used instead of the ${ }^{32} \mathrm{P}-\mathrm{UTP}$. The transcription reaction was stopped by the addition of $10 \%$ trichloroacetic acid (TCA) containing $15 \mathrm{mM}$ sodium pyrophosphate. After incubation on ice for $60 \mathrm{~min}$, the samples were centrifuged at $15000 \mathrm{~g}$ for $20 \mathrm{~s}$. The pellets were washed three times with $3 \%$ TCA containing $15 \mathrm{mM}$ sodium pyrophosphate at $4{ }^{\circ} \mathrm{C}$. The pellets were hydrolyzed with $0.4 \mathrm{M}$ perchloric acid at $70{ }^{\circ} \mathrm{C}$ for $20 \mathrm{~min}$, followed by neutralization with $0 \cdot 4 \mathrm{M}$ $\mathrm{NaOH}$. The total radioactivity released was counted in a liquid scintillation counter.

\section{Transfections}

Stably transfected p53-EGFP-expressing MCF-7 cells were made as follows. Cells were plated onto $6 \mathrm{~cm}$ Falcon plates at $6 \times 10^{5}$ cells/plate in IMEM containing $5 \%$ fetal bovine serum (FBS). After overnight incubation at $37^{\circ} \mathrm{C}$ and $5 \% \mathrm{CO}_{2}$, cells were washed three times with PBS and overlaid with $3 \mathrm{ml}$ fresh IMEM containing 5\% FBS. A mixture of DNA/Superfect reagent (Quiagen Inc., Valencia, CA, USA) was prepared by mixing $2 \mathrm{ng}$ p53-EGFP DNA with $5 \mu \mathrm{l}$ Superfect and serum-free IMEM up to $600 \mu \mathrm{l}$. This mixture was incubated for $10 \mathrm{~min}$ at room temperature to allow DNA/Superfect complex formation. The $600 \mu \mathrm{l} \mathrm{DNA} /$ Superfect mixture was added to the $6 \mathrm{~cm}$ Falcon plate containing the cells in $3 \mathrm{ml}$ IMEM. After 3-h incubation at $37{ }^{\circ} \mathrm{C}$ and $5 \% \mathrm{CO}_{2}$, cells were washed three times with PBS and the selection medium containing Geneticin (G-418) was added.

The ER $\alpha-128$-chloramphenicol acetyl transferase (CAT) vector was constructed using the genomic clone for the ER Q7 (Saceda et al. 1988). The ER $\alpha$ promoter from -128 to +1 nucleotide was generated from Q7 by PCR using primers which also contained a HindIII or XbaI restriction site (AAGCTTGAGTTGTGCCTGGAG and TCTAGAAGCTCCTGGGCTCCC). The PCR product was purified by low melting agarose gel electrophoresis and subcloned into PCR II TA cloning vector (Invitrogen Corp., Carlsbad, CA, USA). The cloning vector containing the insert was then digested with HindIII and XbaI and the DNA fragment was purified by low melting point agarose gel electrophoresis. The purified fragment was subcloned into the polylinker region of pCAT enhancer (Promega, Madison, WI, USA) resulting in ER $\alpha-128-$ CAT. The ER $\alpha-128-\mathrm{CAT}$ vector was sequenced using the Sequenase kit (USB, Cleveland, OH, USA). Transient transfections of MCF-7 cells were performed as described above for stable transfectants but without antibiotic selection and the DNA/Superfect mixture was prepared by mixing $5 \mathrm{ng}$ plasmid and $12 \cdot 5 \mu \mathrm{l}$ Superfect.

\section{DNA electrophoretic mobility shift assay}

MCF-7 cells were grown and treated as described above. Nuclear extracts from control and treated cells were isolated following a protocol described previously (Saceda et al. 1996). For the DNA mobility shift assay, four different ${ }^{32} \mathrm{P}$-labeled oligonucleotides covering the region of the ER gene promoter from -128 to $+1 \mathrm{bp}$ were incubated with nuclear extracts from MCF-7 cells for $20 \mathrm{~min}$ at room temperature in a buffer containing $10 \mathrm{mM}$ Tris (pH 7·5), 100 mM KCl, 1 mM DTT, 1 mM EDTA, and $6 \%$ glycerol. One oligonucleotide, referred to as EP-3, contained the sequence CCTCCAGCACCT TTGTAATGCATATGAGCTCGGG. Samples were loaded onto a $6 \%$ polyacrylamide gel in $1 \times \mathrm{TBE}$ 
(50 mM Tris-borate ( $\mathrm{pH} 8 \cdot 3$ ), and $0.5 \mathrm{mM}$ EDTA) and run at $20 \mathrm{~mA}$ per gel at $4{ }^{\circ} \mathrm{C}$. The gel was dried and autoradiography was performed.
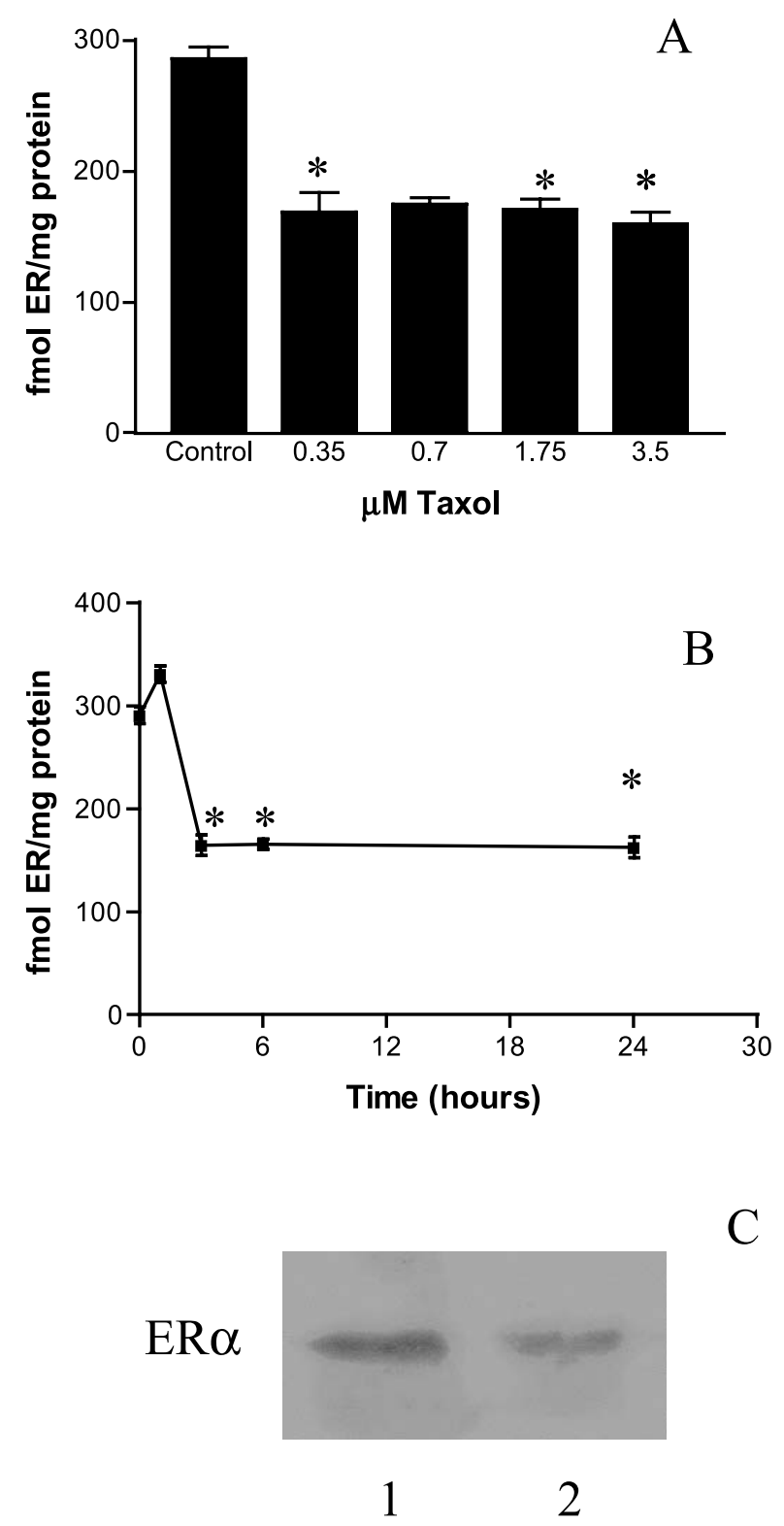

D

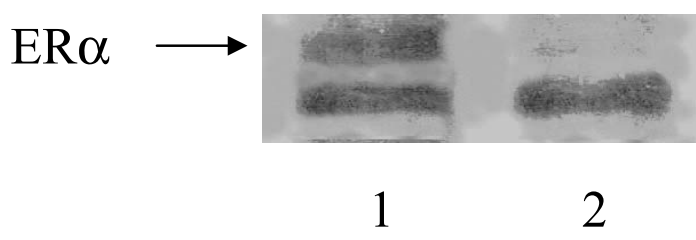

\section{Results}

Effect of taxol treatment on the concentration of ERa protein

To determine whether taxol alters the expression of ER $\alpha$, MCF-7 cells were treated with various concentrations of the drug for $24 \mathrm{~h}$. To measure the amount of ER $\alpha$ protein, an enzyme immunoassay was performed. The data in Fig. 1A demonstrate that treatment with taxol at concentrations from 0.35 to $3.5 \mu \mathrm{M}$ resulted in a decline in total ER $\alpha$ protein by approximately $40 \%$. The concentration of ER $\alpha$ protein declined from $285 \mathrm{fmol} / \mathrm{mg}$ protein in control cells to approximately $171 \mathrm{fmol} / \mathrm{mg}$ protein in treated cells. To define the time-course of this effect, the amount of ER $\alpha$ protein was determined following treatment with $0.35 \mu \mathrm{M}$ taxol. The data in Fig. 1B show that treatment with $0.35 \mu \mathrm{M}$ taxol resulted in a decline in total receptor protein by approximately $40 \%$ in $3 \mathrm{~h}$; the amount of ER $\alpha$ protein remained suppressed for as long as $24 \mathrm{~h}$. These data demonstrate a taxol-mediated decrease in $\mathrm{ER} \alpha$ protein expression in MCF-7 cells. The decrease in ER $\alpha$ protein was also demonstrated by Western blot in total cellular extracts (Fig. 1C) and in membrane extracts (Fig. 1D).

Effect of taxol treatment on the steady-state level of ERa $m R N A$

To determine whether the reduction in ER $\alpha$ protein paralleled a reduction in the steady-state level of ER $\alpha$ mRNA, MCF-7 cells were treated with $0.35 \mu \mathrm{M}$ taxol for various times. The amount of ER $\alpha$ mRNA was measured using an RNase protection assay. In these experiments, changes in ER $\alpha$ mRNA were quantified by scanning densitometry and normalized to the amount of ribosomal protein PO mRNA which is constitutively expressed in the presence of taxol (Fig. 2A). In this study, treatment with $0.35 \mu \mathrm{M}$ taxol resulted in an approximately $75 \%$ increase in the amount of ER $\alpha$ mRNA by $6 \mathrm{~h}$. The amount of ER $\alpha$ mRNA remained elevated for at least $24 \mathrm{~h}$. In contrast to the decrease in ER $\alpha$ protein, taxol induced an increase in ER $\alpha$ mRNA, suggesting that the

Figure 1 Effect of taxol treatment on the concentration of ER $\alpha$ protein. MCF-7 cells were grown in IMEM supplemented with 5\% FCS. When the cells were $80 \%$ confluent, the medium was changed to phenol red-free IMEM and 5\% CCS. Cells were grown in this media for 2-3 days and then treated for $24 \mathrm{~h}$ with taxol $(0 \cdot 35-3 \cdot 5 \mu \mathrm{M})$. Following treatment, the concentration of ER $\alpha$ protein was determined by an enzyme immunoassay as described in Materials and Methods. (A) Effect of taxol treatment on total $E R \alpha$ protein levels. Values are the means \pm S.E.M. of three separate experiments $(n=9)$. ${ }^{*} P<0 \cdot 05$. (B) Time-course of the effect of taxol on the concentration of ER $\alpha$ protein. ${ }^{\star} P<0 \cdot 05$. Effect of taxol treatment on $(\mathrm{C})$ total ER $\alpha$ protein levels and (D) plasma membrane-associated ER $\alpha$ protein determined by Western blot. Lane 1, control MCF-7 cells; lane 2, MCF-7 cells treated with taxol $(0 \cdot 35 \mu \mathrm{M})$ for $24 \mathrm{~h}$. 

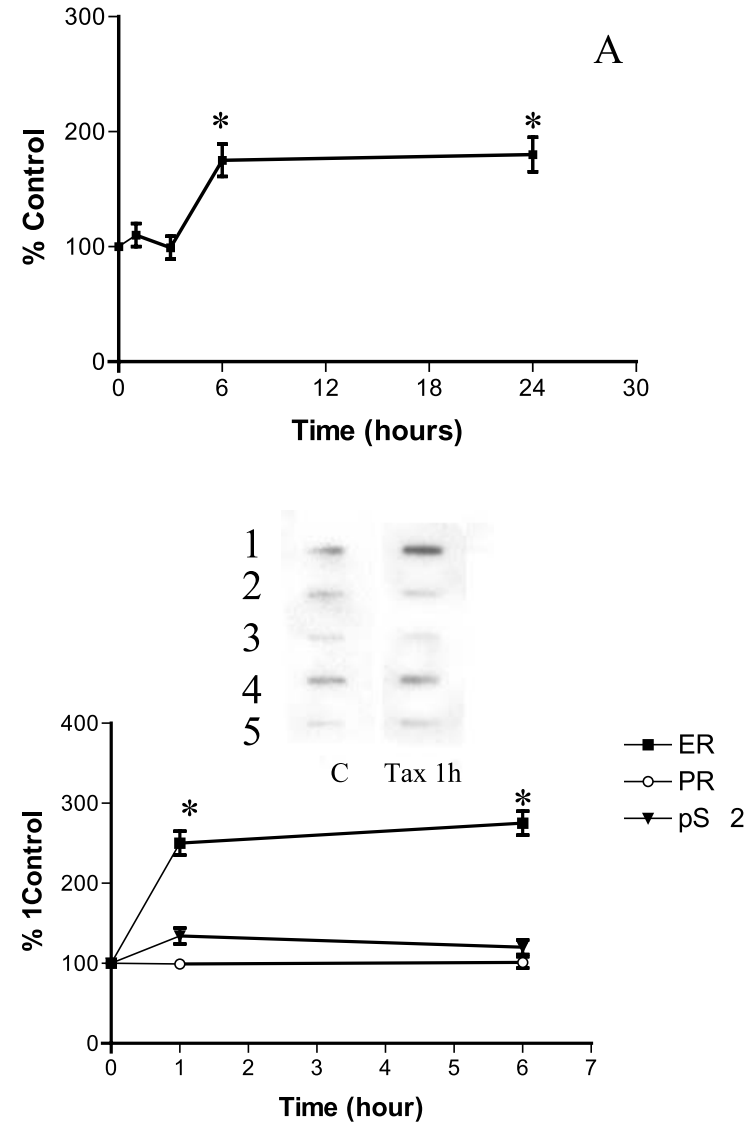

Figure 2 Effect of taxol treatment on the steady-state level of ER $\alpha$ mRNA and on ER $\alpha$ gene transcription. MCF-7 cells were grown and treated with $0.35 \mu \mathrm{M}$ taxol for different times as described in Fig. 1. The amount of ER $\alpha$ mRNA was determined by an RNase protection assay as described in Materials and Methods. For transcription studies, nuclei were isolated, and elongation of transcription was performed as described in Materials and Methods. (A) Effect of taxol on the steady-state level of ER $\alpha$ mRNA. The amount of ER $\alpha$ mRNA was determined by scanning densitometry and normalized to the amount of ribosomal protein PO mRNA. The values are presented as percent of control and are the means \pm S.E.M. of three separate experiments. ${ }^{*} P<0 \cdot 05$. (B) Effect of taxol (Tax) on ER $\alpha$ gene transcription. The levels of ER $\alpha$, $\mathrm{PR}$, and pS2 gene transcription were normalized to the level of ribosomal protein $\mathrm{PO}$ transcription. The results are presented as percent of transcription of untreated cells. Values are the means \pm S.E.M. $(n=4) .{ }^{*} P<0 \cdot 05$. (Inset) Representative nuclear run-on. Line 1, ER $\alpha$; line 2, PO; line 3, GAPDH; line 4, pS2; line $5, P R$.

drug regulates the amount of $\mathrm{ER} \alpha$ protein through either a translational or a post-translational mechanism.

\section{Effect of taxol treatment on the level of ERa gene transcription}

To determine the effect of the drug on ER $\alpha$ gene transcription, transcription run-on assays were performed with nuclei isolated from MCF-7 cells treated with $0 \cdot 35 \mu \mathrm{M}$ taxol. Newly synthesized transcripts were hybridized to probes immobilized on nitrocellulose blots. The level of transcription was determined by autoradiography and quantified by scanning densitometry. Ribosomal protein PO transcription was used as an internal control and the relative changes in ER $\alpha$ transcripts were normalized to the signal obtained for the ribosomal protein. The data in Fig. 2B show a $2 \cdot 5$-fold increase in ER $\alpha$ gene transcription by $1 \mathrm{~h}$ after treatment with taxol. Transcription remained high for at least $6 \mathrm{~h}$. As a control, the transcription of the PR and pS2 genes were analyzed. Data in Fig. 2B show that transcription of both genes was not significantly affected by taxol treatment. To rule out the possibility that the effect on ER $\alpha$ gene transcription was a consequence of a general increase in gene transcription, total transcription was determined in cells treated with $0 \cdot 35 \mu \mathrm{M}$ taxol for 6 or $24 \mathrm{~h}$. Total transcription was determined as the incorporation of ${ }^{3} \mathrm{H}$-uridine per cell. Taxol had no significant effect on total transcription (data not shown). These results demonstrated that the increase in $\mathrm{ER} \alpha$ gene transcription induced by taxol was gene specific and not a consequence of a general increase in total transcription. These data suggest that the increase observed in total ER $\alpha$ mRNA after taxol treatment is due to a specific increase in ER $\alpha$ gene transcription.

\section{Effect of taxol treatment on ERa protein half-life}

To determine if the decrease in ER $\alpha$ protein observed after taxol treatment was due to a decrease in the stability of the ER $\alpha$ protein, the half-life of the $\operatorname{ER} \alpha$ protein was measured following treatment with the drug. To achieve this goal, MCF-7 cells were treated with $0.35 \mu \mathrm{M}$ taxol for $6 \mathrm{~h}$, and then treated with $10 \mu \mathrm{g} / \mathrm{ml}$ cycloheximide to block protein biosynthesis. ER $\alpha$ protein content was determined at different times after addition of cycloheximide. Data shown in Fig. 3 demonstrate that there was no difference in the ER $\alpha$ half-life after treatment with taxol. The half-life in control and treated cells was approximately $3 \mathrm{~h}$. These results suggested that the decrease in ER $\alpha$ protein observed after taxol treatment was not due to a decrease in ER $\alpha$ half-life, but may be due to a general effect of the drug on protein biosynthesis or to a specific effect on ER $\alpha$ protein synthesis. To distinguish between these possibilities, the incorporation of ${ }^{3} \mathrm{H}$-amino acids into proteins was measured in cells treated with $0.35 \mu \mathrm{M}$ taxol. These data demonstrate that taxol had no significant effect on protein synthesis (data not shown), suggesting that the effect of taxol on ER $\alpha$ protein is specific and not due to a non-specific decrease in total protein biosynthesis.

\section{Determination of ERa promoter region responsible for taxol regulation}

To identify the region of the ER $\alpha$ promoter responsible for the taxol-induced increase in transcription, transient transfection assays were conducted using deletion mutants 


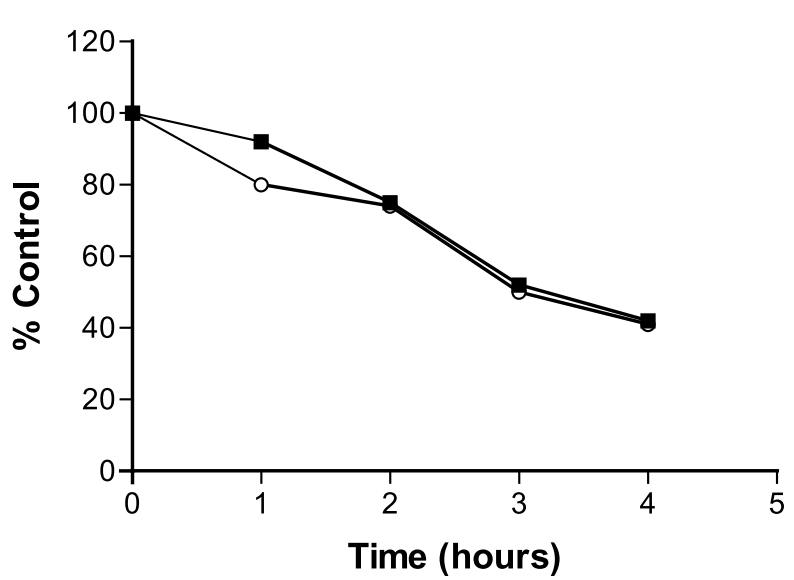

Figure 3 Effect of taxol treatment on ER $\alpha$ protein half-life. MCF-7 cells were grown as described in Fig. 1. Following 2 days in phenol red-free IMEM and 5\% CCS, the cells were treated with $0.35 \mu \mathrm{M}$ taxol $(\bigcirc)$. After $6 \mathrm{~h}$, cycloheximide $(10 \mu \mathrm{g} / \mathrm{ml})$ was added and the loss of ER $\alpha$ protein was determined by enzyme immunoassay. Control ( $\mathbf{\square})$. The results are presented as percent of control from the time of cycloheximide addition.

of the ER $\alpha$ promoter from -3200 to $-40 \mathrm{bp}$. These studies indicated that the effects of taxol were mediated by the proximal $128 \mathrm{bp}$ in promoter A (data not shown). Promoter A from -128 to $+1 \mathrm{bp}$ was then subcloned upstream of a CAT reporter gene in a construct that also contained an SV40 enhancer. Data presented in Fig. 4A showed a tenfold increase in CAT activity in MCF-7 cells treated with taxol. Interestingly, the same reporter was induced by transient cotransfection with the wild-type p53 gene. To further characterize the region of promoter A involved in the regulation of transcription by taxol, four oligonucleotides, which covered the entire $128 \mathrm{bp}$ region of promoter A, were synthesized and named EP-1 to EP-4. To test the ability of nuclear extracts from taxoltreated cells to bind to the different regions of the ER $\alpha$ promoter, DNA electrophoretic mobility shift assays were performed with nuclear extracts isolated from cells treated with $0.35 \mu \mathrm{M}$ taxol for either 1 or $6 \mathrm{~h}$. The protein-bound probes were separated from free probe by electrophoresis on native polyacrylamide gels. The results of the mobility shift assays showed no detectable difference in the migration patterns of probes EP-1, EP-2, and EP-4 when the probes were incubated with nuclear extracts isolated from either control or treated cells (data not shown). However, with the EP-3 oligonucleotide, a new band appeared in the cells treated with taxol (Fig. 4B). The intensity of the band increased along with the time of treatment and was competed with an excess of cold EP-3, suggesting the formation of a specific taxol-induced complex with EP-3. However, an excess of cold EP-2 and EP-1 were unable to compete the specific binding to EP-3 (Fig. 4C). Antibodies against p53 also blocked the formation of the taxol-induced complex, providing additional evidence for a role of p53 in the regulation of ER $\alpha$ gene transcription.
To further explore whether p53 may be involved in taxol regulation of ER $\alpha$ gene transcription, the effects of taxol treatment on p53 levels and activity were determined. First, the amount of p53 mRNA was measured after taxol treatment. As shown in Fig. 5A, taxol treatment induced an increase in p53 mRNA in MCF-7 cells. Furthermore, taxol treatment induced an increase in p53 protein in MCF-7 cells stably transfected with a p53-EGFP chimera (Fig. 5B). As a positive control for p53 induction, MCF-7 cells transfected with the chimera were treated with trichostatin A and daunomycin (data not shown). These data suggest that the taxol-induced increase in ER $\alpha$ transcription may be mediated by the induction of p53.

\section{Discussion}

The results presented herein demonstrate two different effects of taxol on ER $\alpha$ expression. Treatment of MCF-7 cells with concentrations of taxol from 0.35 to $3.5 \mu \mathrm{M}$ resulted in a rapid decline in total ER $\alpha$ protein. This decrease remained constant for at least $24 \mathrm{~h}$. Interestingly, the overall decrease in ER $\alpha$ protein was not paralleled by a decrease in ER $\alpha$ mRNA; on the contrary, a significant increase in ER $\alpha$ mRNA was observed after taxol treatment. The increase in ER $\alpha$ mRNA was due to a transcriptional effect as demonstrated by nuclear run-on assays. The decrease in ER $\alpha$ protein concentration, even in the presence of an increase in ER $\alpha$ mRNA, was not due to a decrease in the ER $\alpha$ protein half-life, suggesting that taxol blocked the biosynthesis of ER $\alpha$. The effects of taxol on the transcription and translation of ER $\alpha$ were not due to non-specific effects on total transcription or protein biosynthesis as demonstrated by the lack of an effect of taxol on the incorporation of ${ }^{3} \mathrm{H}$-uridine and ${ }^{3} \mathrm{H}$-amino acid into macromolecules. In addition, taxol had no effect on the transcription of the PR, pS2, and ribosomal protein PO genes. Taken together, these data demonstrate multiple effects of taxol on ER $\alpha$ expression: (1) a specific increase in the transcription of the ER $\alpha$ gene and (2) a specific decrease in the biosynthesis of $\operatorname{ER} \alpha$ protein.

Taxol has many biological effects which appear to be related to its ability to promote the assembly of microtubules and to stabilize microtubules against depolymerization (Schiff \& Horwitz 1980). The effect on the microtubule network produces a block in cell division which makes taxol a potent therapeutic drug against several types of cancer (Long 1994, Crown \& O'Leary 2000, Mukherjee et al. 2001). However, the effects of taxol on ER $\alpha$ described in the present report are difficult to explain based exclusively on its effect on microtubules and may be related to an effect on signal transduction pathways. The increase in ER $\alpha$ gene transcription is rapid and occurs within $1 \mathrm{~h}$ of treatment with taxol, suggesting that the changes in expression or activity of signal transduction pathways rather than changes in microtubules are 

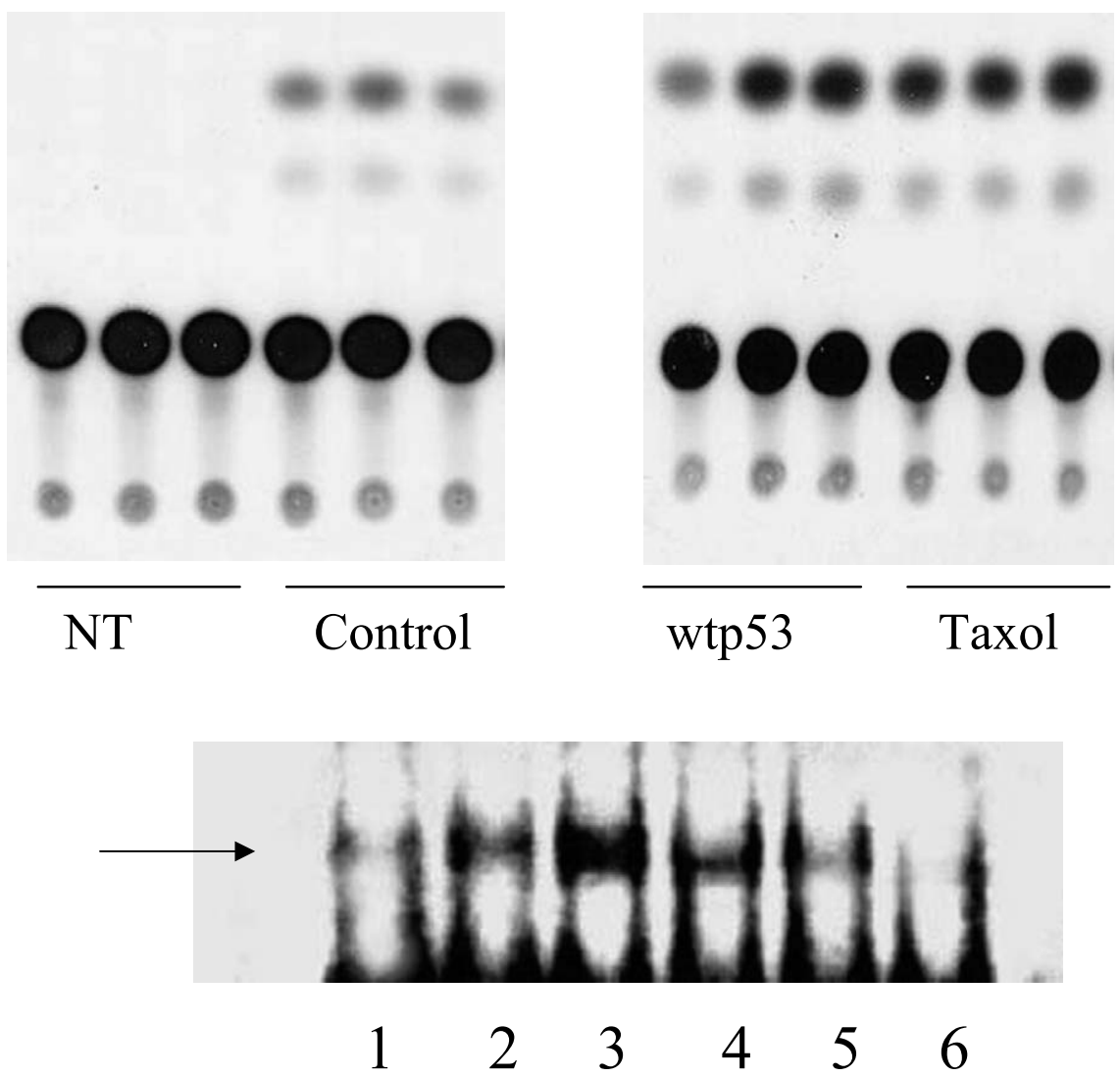

$\mathrm{B}$

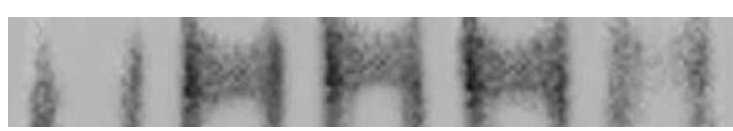

\section{$\begin{array}{lllll}1 & 2 & 3 & 4 & 5\end{array}$}

Figure 4 Transcriptional regulation of ER $\alpha$ promoter by taxol treatment. MCF-7 cells were grown as described in Fig. 1. (A) Effect of taxol on activity of the ER $\alpha$ promoter. MCF-7 cells were transiently transfected with a construct containing the first $128 \mathrm{bp}$ of promoter A of the ER $\alpha$ gene driving the expression of the CAT reporter gene. CAT activity was determined by thin-layer chromatography. NT, control non-transfected cells; control, MCF-7 cells transfected with the CAT reporter gene; wild-type p53 (wp53), MCF-7 cells cotransfected with the CAT reporter gene and the wild-type p53 gene; taxol, MCF-7 cells transfected with the CAT reporter gene and treated with taxol. Triplicates of each condition are shown. (B) Effects of taxol on complex formation with the ER $\alpha$ promoter. MCF-7 cells were treated with $0.35 \mu \mathrm{M}$ taxol at different incubation times and nuclear extracts were obtained as described in Materials and Methods. Binding of the ${ }^{32}$ P-labeled EP-3 oligonucleotide to nuclear extracts was determined by a DNA electrophoretic mobility shift assay. Lane 1, binding to nuclear extracts from untreated cells; lane 2, binding to nuclear extracts from cells treated with taxol for $1 \mathrm{~h}$; lane 3, binding to nuclear extracts from cells treated with taxol for $6 \mathrm{~h}$. Lanes 4 and 5 show nuclear extracts from taxol-treated cells competed with two different p53 antibodies. Lane 6 shows competition with an excess of cold EP-3 Arrow, specific binding of EP-3 to nuclear extracts. (C) As (B) except: lane 1, binding to nuclear extracts from untreated cells; lane 2, binding to nuclear extracts from cells treated with taxol for 6 h; lanes 3 and 4, binding to nuclear extracts from cells treated with taxol for $6 \mathrm{~h}$ competed with an excess of cold EP-2 and EP-1 respectively. Lane 5 shows competition with an excess of cold EP-3. 


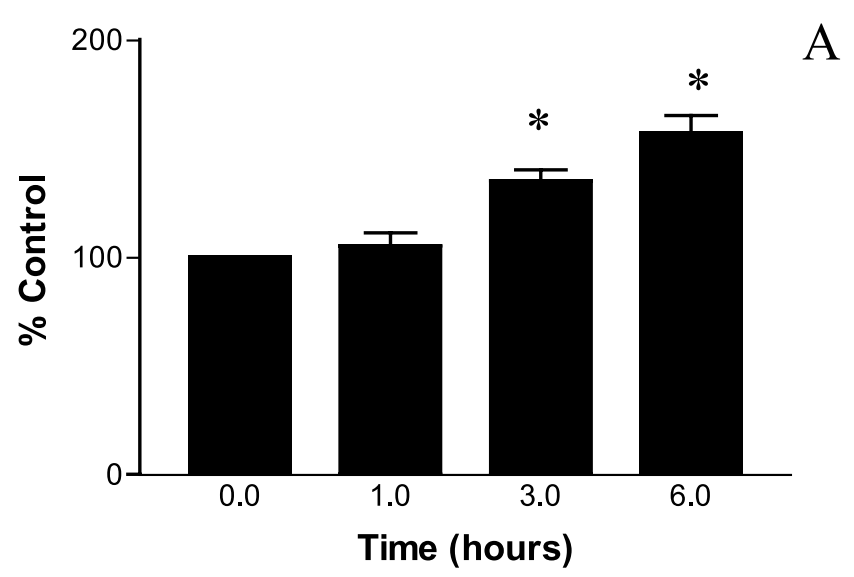

$\mathrm{B}$
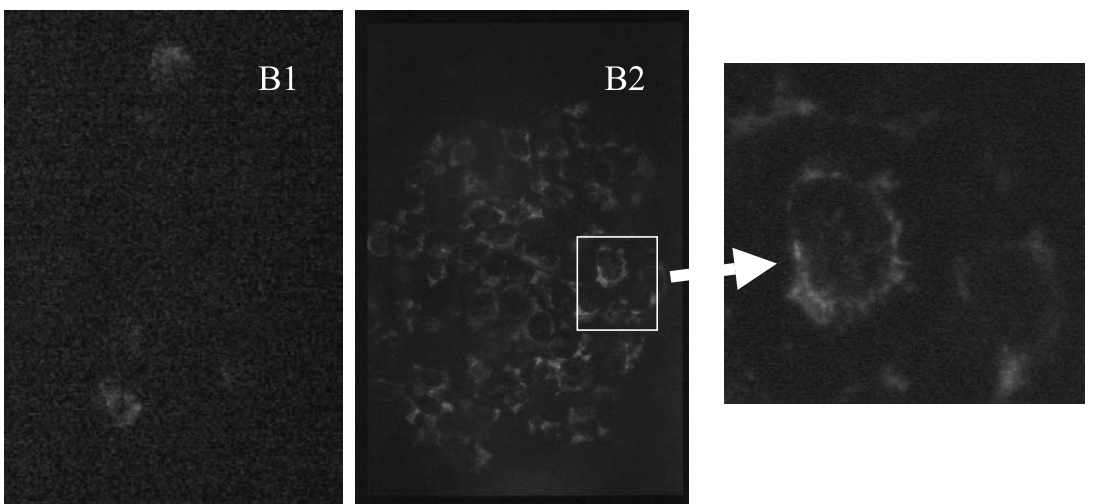

Figure 5 Effect of taxol treatment on the expression of p53. MCF-7 cells were grown as described in Fig. 1 and treated with $0.35 \mu \mathrm{M}$ taxol. (A) Effect of taxol on the steady-state levels of p53 mRNA. MCF-7 cells were treated with taxol for different times and the amount of mRNA was determined by an RNase protection assay as described in Materials and Methods. Results are shown as percent of control untreated cells. Values are the means \pm S.E.M. $(n=4)$. ${ }^{*} P<0 \cdot 05$. (B) Effect of taxol treatment on p53 stability in MCF-7 cells stably transfected with a p53-EGFP chimera. (B1) Control cells; (B2) cells treated with $0 \cdot 35 \mu \mathrm{M}$ taxol for $1 \mathrm{~h}$.

responsible for the increase in ER $\alpha$ transcription. However, it is not possible at the present time to rule out the possibility that the interaction of taxol with microtubules results in a rapid activation of signal transduction pathways. The dual effect of taxol on catecholamine secretion in chromaffin cells appears to involve both signal transduction pathways and microtubules (Thuret-Carnahan et al. 1985, Gomez et al. 2000). During the first hour of treatment, taxol induces an increase in catecholamine release, but at longer times the drug blocks the release of catecholamines (Thuret-Carnahan et al. 1985). The authors suggest that taxol has two different mechanisms of action. Initially, taxol induces an increase in intracellular $\mathrm{Ca}^{2+}$ concentration that triggers the increase in secretion observed within the first hour of treatment, whereas the later inhibitory effect is mediated by the effect of the drug on microtubules involved in the secretory process (Thuret-Carnahan et al. 1985).

The transcriptional effect of taxol on the ER $\alpha$ promoter may be due, in part, to the induction of p53. Similar to other studies (Tishler et al. 1995), taxol caused the rapid induction of $\mathrm{p} 53$, as we have demonstrated with the p53-EGFP chimera experiments. When transfected into MCF-7 cells, p53 increased transcription from the ER $\alpha$ promoter. In addition, p53 appears to interact with the complex that binds with the region of the ER $\alpha$ promoter involved in mediating the effects of taxol. However, there is no p53 consensus sequence within 
this region, suggesting that the interaction of $\mathrm{p} 53$ with the $\mathrm{ER} \alpha$ promoter is indirect. In support of an indirect mechanism, we have unpublished data demonstrating that p53 mutants that do not bind the DNA are able to induce ER $\alpha$ expression, while p53 mutations that interfere with protein-protein interactions block ER $\alpha$ induction.

Although the mechanisms involved in the taxolinduced inhibition of ER $\alpha$ translation are unknown, it is interesting to speculate that the effects of taxol may be mediated by TNF. Taxol is known to induce TNF (Burkhart et al. 1994), which in turn may repress translation through the phosphorylation of eukaryotic initiation factor- $2 \alpha$ by the double-stranded RNA-activated protein kinase. It is also possible that the effects of taxol on ER $\alpha$ translation are independent of the TNF pathway. Taxol also affects the translation of tubulin mRNA. In the case of tubulin, the effects of taxol are due to an effect on tubulin mRNA half-life (Gong \& Brandhorst 1988). Alternatively, the effects of taxol on the synthesis of ER $\alpha$ protein may be mediated by $\mathrm{p} 53$. The p53 protein is known to bind to the $5^{\prime}$ untranslated region of $c d k 4$ and to mediate the inhibitory effects of transforming growth factor- $\beta$ on the expression of $c d k 4$ (Miller et al. 2000). It is also worth noting that cytoplasmic p53 is associated with a subset of ribosomes (Stein 1999).

$\mathrm{ER} \alpha$ regulation in breast cancer cells is a complex phenomenon occurring at the transcriptional and posttranscriptional levels. Many factors including estradiol, anti-estrogens, phorbol esters, growth factors, and ions such as cadmium regulate the expression of ER $\alpha$ (Saceda et al. 1988, 1991, 1996, Lee et al. 1989, Cho et al. 1991, Garcia-Morales et al. 1994, Martin et al. 1995, Stoica et al. 1997, 2000a,b). Some of these compounds regulate ER $\alpha$ gene transcription, such as estradiol (Saceda et al. 1988, Cho et al. 1991), cadmium (Garcia-Morales et al. 1994), and gp30 (Saceda et al. 1996), while others affect the concentration of ER $\alpha$ through post-transcriptional mechanisms, e.g. estradiol (Saceda et al. 1988) and phorbol esters (Saceda et al. 1991). These findings suggest that ER $\alpha$ regulation is affected by many different stimuli in breast cancer cells. In fact, ER $\alpha$ could be regulated at the translational level because several upstream open reading frames have been described for this gene (Kos et al. 2002). For this reason, it is not difficult to imagine an effect of taxol on ER $\alpha$ levels. However, it still remains unclear as to whether the effects of the drug on the expression of $\operatorname{ER} \alpha$ is the basis of its powerful response in hormoneregulated cancers such as breast carcinoma (Fornier et al. 2000).

\section{Acknowledgements}

This work was supported, in part, by NIH CA59493 and by Generalitat Valenciana, GVDOC98-VS-23-13.

\section{References}

Adams JD, Flora KP, Goldspiel BR, Wilson JW, Arbuck SG \& Finley R 1993 Taxol: a history of pharmaceutical development and current pharmaceutical concerns. Journal of the National Cancer Institute 15 141-147.

Allegra JC \& Lippman ME 1980 Estrogen receptor status and the disease-free interval in breast cancer. Recent Results in Cancer Research 71 20-25.

Baker SJ, Markowitz S, Fearon ER, Willson JK \& Vogelstei B 1990 Suppression of human colorectal carcinoma cell growth by wild-type p53. Science 249 912-915.

Berthois Y, Katzenellenbogen JA \& Katzenellenbogen BS 1986 Phenol red in tissue culture is a weak estrogen: implications concerning the study of estrogen-responsive cells in culture. PNAS 83 2496-2500.

Burkhart CA, Berman JW, Swindell CS \& Horwitz SB 1994 Relationship between the structure of taxol and other taxanes on induction of tumor necrosis factor-alpha gene expression and cytotoxicity. Cancer Research 54 5779-5782.

Cho HS, Pa NG \& Katzenellenbogen BS 1991 Differential regulation of gene expression by estrogen in estrogen-independent and -dependent MCF-7 human breast cancer cell sublines. Molecular Endocrinology 5 1323-1330.

Chomczynski P \& Sacchi N 1987 Single-step method of RNA isolation by acid guanidinium thiocyanante-phenol-chloroform extraction. Analytical Biochemistry 162 156-159.

Crown J \& O'Leary M 2000 The taxanes: an update. Lancet 355 1176-1178.

DeSombre ER \& Jensen EV 1980 Estrophilin assays in breast cancer: quantitative features and application to the mastectomy specimens. Cancer 46 2783-2788.

Fornier M, Esteva FJ \& Seidman AD 2000 Trastuzumab in combination with chemotherapy for the treatment of metastatic breast cancer. Seminars in Oncology 27 38-45.

Garcia-Morales P, Saceda M, Kenney N, Kim N, Salomon DS, Gottardis MM, Solomon HB, Sholler PF, Jordan VC \& Martin MB 1994 Effect of cadmium on estrogen receptor levels and estrogeninduced responses in human breast cancer cells. Journal of Biological Chemistry 269 16896-16901.

Gomez AM, Kerfant BG \& Vassort G 2000 Microtubule disruption modulates $\mathrm{Ca}(2+)$ signaling in rat cardiac myocytes. Circulation Research 86 30-36.

Gong ZY \& Brandhorst B 1988 Autogenous regulation of tubulin synthesis via RNA stability during sea urchin embryogenesis. Development 102 31-43.

Joseph JP, Grierson I \& Hitchings RA 1989 Taxol, cytochalasin B and colchicine effects on fibroblast migration and contraction: a role in glaucoma filtration surgery? Current Eye Research 8 203-215.

Kern SE, Pietenpol JA, Thiagalingam S, Seymour A, Kinzler KW \& Vogelstein B 1992 Oncogenic forms of p53 inhibit p53-regulated gene expression. Science 256 827-830.

Kos M, Denger S, Reid G \& Gannon F 2002 Upstream open reading frames regulate the translation of the multiple mRNA variants of the estrogen receptor $\alpha$. Journal of Biological Chemistry 277 37131-37138.

Lee CS, Koga M \& Sutherland RL 1989 Modulation of estrogen receptor and epidermal growth factor receptor mRNAs by phorbol ester in MCF-7 breast cancer cells. Biochemical and Biophysical Research Communications 162 415-421.

Long HJ 1994 Paclitaxel (Taxol): a novel anticancer chemotherapeutic drug. Mayo Clinic Proceedings 69 341-345.

Martin MB, Garcia-Morales P, Stoica A, Solomon HB, Katz D, Zhang S, Danielson M \& Saceda M 1995 Effects of 12-Otetradecanoylphorbol-13-acetate on estrogen receptor activity in MCF-7 cells. Journal of Biological Chemistry 270 25244-25251. 
Milas L, Hunter NR, Kurdoglu B, Mason KA, Meyn RE, Stephens LC \& Peters LJ 1995 Kinetics of mitotic arrest and apoptosis in murine mammary and ovarian tumors treated with taxol. Cancer Chemotherapy and Pharmacology 35 297-303.

Miller SJ, Suthiphongchai T, Zambetti GP \& Ewen ME 2000 p53 binds selectively to the $5^{\prime}$ untranslated region of $\mathrm{cdk} 4$, an RNA element necessary and sufficient for transforming growth factor beta- and p53-mediated translational inhibition of cdk4. Molecular and Cellular Biology 20 8420-8431.

Milross CG, Mason KA, Hunter NR, Chung WK, Peters LJ \& Milas L 1996 Relationship of mitotic arrest and apoptosis to antitumor effect of paclitaxel. Journal of the National Cancer Institute 88 1308-1314.

Moos PJ \& Fitzpatrick FA 1998 Taxane-mediated gene induction is independent of microtubule stabilization: induction of transcription regulators and enzymes that modulate inflammation and apoptosis. PNAS 95 3896-3901.

Mukherjee AK, Basu S, Sarkar N \& Ghosh AC 2001 Advances in cancer therapy with plant based natural products. Current Medicinal Chemistry 8 1467-1486.

Osborne CK, Yochmowitz MG, Knight WAI \& McGuire WL 1980 The value of estrogen and progesterone receptors in the treatment of breast cancer. Cancer 46 2884-2888.

Paridaens R, Sylvester RJ, Ferrazzi E, Legros N, LeClercq G \& Hensen JC 1980 Clinical significance of the quantitative assessment of estrogen receptors in advanced breast cancer. Cancer 46 2889-2895.

Pletjushkina OJ, Ivanova OJ, Kaverina IN \& Vasiliev JM 1994 Taxol-treated fibroblasts acquire an epithelioid shape and a circular pattern of actin bundles. Experimental Cell Research 212 201-208.

Saceda M, Lippman ME, Chambon P, Lindsey RK, Pongliktmongkol M, Puente M \& Martin MB 1988 Regulation of the estrogen receptor in MCF-7 cells by estradiol. Molecular Endocrinology 2 $1157-1162$.

Saceda M, Knabbe C, Dickson RB, Lippman ME, Bronzert D, Lindsey RK, Gottardis MM \& Martin MB 1991 Posttranscriptional destabilization of estrogen receptor mRNA in MCF-7 cells by 12-O-tetradecanoylphorbol-13-acetate. Journal of Biological Chemistry 266 17809-17814.

Saceda M, Grunt TW, Colomer R, Lippman ME, Lupu R \& Martin MB 1996 Regulation of estrogen receptor concentration and activity by an erbB/HER ligand in breast carcinoma cell lines. Endocrinology 137 4322-4330.

Schiff PB \& Horwitz SB 1980 Taxol stabilizes microtubules in mouse fibroblast cells. PNAS 77 1561-1565.

Srivastava RK, Srivastava AR, Korsmeyer SJ, Nesterova M, Cho-Chung YS \& Longo DL 1998 Involvement of microtubules in the regulation of $\mathrm{Bcl} 2$ phosphorylation and apoptosis through cyclic AMP-dependent protein kinase. Molecular and Cellular Biology 18 3509-3517.

Stein CA 1999 Mechanisms of action of taxanes in prostate cancer. Seminars in Oncology 26 3-7.

Stoica A, Saceda M, Fakhro A, Solomon HB, Fenster BD \& Martin MB 1997 The role of transforming growth factor-B in the regulation of estrogen receptor expression in the MCF-7 breast cancer cell line. Endocrinology 138 1498-1505.

Stoica A, Saceda M, Doraiswamy VL, Coleman C \& Martin MB $2000 a$ Regulation of estrogen receptor-alpha gene expression by epidermal growth factor. Journal of Endocrinology 165 371-378.

Stoica A, Saceda M, Fakhro A, Joyner M \& Martin MB $2000 b$ Role of insulin-related growth factor-I in the regulation of estrogen receptor-alpha gene expression. Journal of Cellular Biochemistry 76 605-614.

Thuret-Carnahan J, Bossu JL, Feltz A, Langley K \& Aunis D 1985 Effect of taxol on secretory cells: functional, morphological, and electrophysiological correlates. Journal of Cellular Biochemistry 100 1863-1874.

Tishler RB, Lamppu DM, Park S \& Price BD 1995 Microtubuleactive drugs taxol, vinblastine, and nocodazole increase the levels of transcriptionally active p53. Cancer Research 55 6021-6025.

Wang LG, Liu XM, Kreis W \& Budman DR 1999 The effect of antimicrotubule agents on signal transduction pathways of apoptosis: a review. Cancer Chemotherapy and Pharmacology 44 355-361.

Wani MC, Taylor HL, Wall ME, Coggon P \& McPhail AT 1971 Plant antitumor agents. VI. The isolation and structure of taxol, a novel antileukemic and antitumor agent from Taxus brevifolia. Journal of the American Chemical Society 93 2325-2327.

Received in final form 5 December 2003 Accepted 9 December 2003 